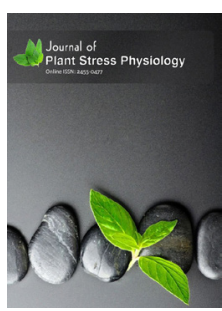

ISSN: $2455^{-0} 0477$

Received: April 11, 2019

Accepted: June 19, 2019

Published: June 26, 2019

*Corresponding Author:

S. Vasantha

Email: vasanthavedantham

@yahoo.com

\section{The response of sugarcane genotypes subjected to salinity stress at different growth phases}

\author{
C. Brindha, S. Vasantha*, R. Arunkumar \\ Division of Crop Production, ICAR-Sugarcane Breeding Institute, Coimbatore- 641007, Tamil Nadu, India
}

\begin{abstract}
A few commercial sugarcane genotypes were subjected to salinity stress at various growth phases of sugarcane to ascertain the critical growth stage for salinity stress and to assess the response of the genotypes. All the data were recorded and analysed during maturity phase. The salt treatments drastically reduced SPAD chlorophyll, chlorophyll fluorescence, RWC, stalk height, weight and other yield parameters in a few genotypes during T2 (salt treatment given during formative phase) \& T5 (salt treatment given throughout crop cycle) but a few genotypes which are tolerant towards salt stress gave better results comparing other genotypes. The ions like sodium, potassium and chloride were analysed in the juice which showed higher elevation in the genotype Co 97010. Among the genotypes, Co 85019 and Co 99004 recorded significantly prime compared to rest of the genotypes. Treatment throughout the growth phases $\left(\mathrm{T}_{5}\right)$ followed by stress at formative phase (T2) were found to be critical for growth, physiological and yield responses in all the genotypes.
\end{abstract}

KEYWORDS: Salinity stress, sugarcane, physiological parameters, yield parameters

\section{INTRODUCTION}

In India nearly 9 million hectares area is occupied by saltaffected soils out of which 5.5 million hectares are saline soils. Salinity adversely affects crop production all over the world [1]. Saline soil is an inevitable component of arid and semi-arid region. Sugarcane is a typical glycophyte, which exhibit stunted growth or zero growth under salinity. About $40 \%$ of yield loss was reported in salinity affected areas. Sugarcane genotypes greatly differ in their ability to grow in saline condition. A report show a steep decline in growth once the soil $\mathrm{EC}$ rises above $3 \mathrm{dS} \mathrm{m}^{-1}$ [2]. There was also a report indicating $0 \%$ decrease in yield at an EC of $1.7 \mathrm{dS} \mathrm{m}^{-1}, 10 \%$ at $3.3,25 \%$ at $6,50 \%$ at 10.4 and $100 \%$ at an EC $18.6 \mathrm{dS} \mathrm{m}^{-1}$ respectively [3]. The EC value of $5.0 \mathrm{dS} \mathrm{m}^{-1}$ leads to overall reduction in germination $(30.28 \%)$, cane weight $(25.72 \%)$ cane yield $(28.05 \%)$ and sugar yield $(33.25 \%)$ [4]. Salinity levels $(100$ and $200 \mathrm{mM} \mathrm{NaCl})$ were shown to have detrimental effect on chlorophyll fluorescence [5].

The leaf growth parameters were reduced with increasing salinity and the concentration of $\mathrm{Cl}^{-}$ions in the third visible dewlap leaf was 10 times higher than that of $\mathrm{Na}^{+}$ions [6]. A report has shown that the sucrose concentration was reduced by increasing $\mathrm{KCl}$ levels but not by $\mathrm{K}_{2} \mathrm{SO}_{4}$ levels [7]. Accumulation of high concentration ions in sink cells might have affected the expression of invertase gene [8].
Sugarcane grown in saline soil experiences the adverse growth and development behaviour throughout the crop cycle, as soil salinity is long lasting unless, soil reclamation has to be done to remove the salts. However, during monsoon rainfall periods, a temporary relief is experienced, as the soluble salts would be removed from root zone through run off effect. The present study focuses on identifying critical phenophase of the crop, once identified can be matched with monsoon periods to mitigate stress effect. The varietal response to salt stress at different growth phases was also a component of the study is to determine the tolerance level of commercial cultivars.

\section{MATERIALS AND METHODS}

\section{Experimental Design and Imposition of Treatments}

A pot experiment was conducted with eight commercial genotypes namely Co 8021, Co 85019, Co 2001-13, Co 97010, Co 99004, Co 94012 Co 95007 and Co 97009 with three replicates for each variety. Salt treatment was given with combination of three salts (sodium chloride, calcium chloride and sodium sulphate) in the ratio of 2:2:1 to raise soil EC up to $8 \mathrm{dS} \mathrm{m}^{-1}$ at different growth stages namely $\mathrm{T}_{2}$ (formative phase 60 to 150 days), $\mathrm{T}_{3}$ (grand growth phase 150 to 240 days), $\mathrm{T}_{4}$ (maturity phase 240 to 360 days), $\mathrm{T}_{5}$ (throughout the crop cycle) and a control with normal irrigation as $\mathrm{T}_{1}$.

Copyright: $\odot$ The authors. This article is open access and licensed under the terms of the Creative Commons Attribution License (http://creativecommons.org/licenses/by/4.0/) which permits unrestricted, use, distribution and reproduction in any medium, or format for any purpose, even commercially provided the work is properly cited. Attribution - You must give appropriate credit, provide a link to the license, and indicate if changes were made. 


\section{Physiological Traits}

During the growth phases, physiological traits namely chlorophyll fluorescence, chlorophyll SPAD index and RWC (relative water content) were estimated. Chlorophyll Fluorescence (fv/fm ratio) was measured using Chlorophyll Fluorometer (model OS-30p) during 9:00am to 11:00am. Chlorophyll SPAD index was recorded with SPAD-502 (Konica Minolata Sensing,Inc.) on clear light between 9:00am to 11:00am.

RWC was estimated using the standard formula [9].

\section{Data Harvest, Juice Quality Analysis}

Plant characters namely plant height, number of stalk per pot were recorded. Cane yield, single cane weight was recorded at the completion of experiment. Sugarcane juice was extracted in crusher (65\% capacity) and juice volume was measured in litres and juice was analyzed for brix (\%), pol (\%) and purity (\%) as per standard methods [10]. Nutrients viz., potassium, sodium and chloride in the juice were estimated using flame photometer [11].

\section{Statistical Analysis}

The data on chlorophyll fluorescence, SPAD chlorophyll index, relative water content, plant height, single cane weight, number of stalks, cane yield, brix, sucrose, CCS and purity percent, nutrients such as sodium, potassium and chloride in juice were analyzed based on three replications and the results were expressed as mean values. Analysis of variance was performed and significance of each group was verified with two-way analysis of variance. The statistical analysis was performed using the software JMP 9.0.

\section{RESULTS AND DISCUSSION}

\section{Physiological Traits}

\section{Chlorophyll fluorescence}

Chlorophyll fluorescence varied from 0.659 (Co 2001-13) to 0.684 (Co 85019) among the genotypes in control (Table 1).
In $T_{2}$ the highest was recorded in Co 85019 (0.647) and the least was found in Co 8021 (0.575), the same trend was also seen in the salt treatment $\left(\mathrm{T}_{5}\right)$ where the salt treatment was given throughout the growth stages. In $\mathrm{T}_{5}$ Co 85019 it was 0.633 and in Co 8021 it was 0.542 . So, $\mathrm{T}_{2}$ (salt treatment given during formative phase) was found to be the critical stage. $T_{3}$ and $\mathrm{T}_{4}$ have no ill effect when compared to $\mathrm{T}_{2}$ and $\mathrm{T}_{5}$. In $\mathrm{T}_{3}$ it varied from 0.594 (C0 8021) to 0.662 (Co 85019). Therefore it was perceived that, the salt treatments at formative phase and throughout the crop cycle has similar declining trend with respect to chlorophyll fluorescence. Chlorophyll fluorescence is a very sensitive tool in the study of stress-induced damage to PSII [12]. There was also a review about the decrease in $\mathrm{Fv} / \mathrm{Fm}$ ratio in salinity [13].

\section{SPAD Chlorophyll Index}

SPAD measurements are widely used to assess the absolute chlorophyll content per leaf area. SPAD index varied from 37.27 (Co 8021) to 40.18 (Co 97009) in $\mathrm{T}_{1}$ (Table 1). It was decreased in $\mathrm{T}_{2}$, the highest was observed in the genotype Co 85019 (37.7) and the least was recorded in the genotype Co 97010 (34.57). In treatments $\mathrm{T} 3$ and $\mathrm{T} 4$ reduction was marginal but in $\mathrm{T} 5$ there was a notable drop in SPAD index, where the least value of 29.09 was observed in the genotype Co 97010. The treatments $\mathrm{T}_{2}$ and $\mathrm{T}_{5}$ had similar trend for chlorophyll SPAD value again suggesting formative phase to be sensitive to salinity stress. It confirms formative phase as critical stage of crop growth under salinity [14].

\section{Relative Water Content (\%)}

Relative water content varied from $69 \%$ to $80 \%$ among the genotypes in $\mathrm{T}_{1}$ (control), while in $\mathrm{T}_{2}$ it ranged from 48 to $70 \%$ with Co 97010 recording least turgidity; $\mathrm{T}_{2}$ is in line with $\mathrm{T}_{5}$ indicating stress severity on leaf moisture content during formative phase is effective (Table 1). Specific salt treatments during grand growth phase $\left(\mathrm{T}_{3}\right)$ and maturity phase $\left(\mathrm{T}_{4}\right)$ did not affect the relative water content as severely as in $\mathrm{T}_{2}$ and $\mathrm{T}_{5}$. Earlier report also had a similar finding [15].

Chlorophyll fluorescence an indication of active photochemical activity decreased in all the growth phases due to salinity and

Table 1. Effect of salt stress on physiological parameters

\begin{tabular}{|c|c|c|c|c|c|c|c|c|c|c|c|c|c|c|c|c|c|c|}
\hline \multirow{2}{*}{$\begin{array}{l}\text { Treatments/ } \\
\text { varieties }\end{array}$} & \multicolumn{6}{|c|}{ Chlorophyll Fluorescence } & \multicolumn{6}{|c|}{ SPAD Chlorophyll } & \multicolumn{6}{|c|}{ Relative water content (\%) } \\
\hline & $\mathrm{Tl}$ & $\mathrm{T} 2$ & T3 & T4 & T5 & Mean & $\mathrm{Tl}$ & $\mathrm{T} 2$ & T3 & T4 & T5 & Mean & $\mathrm{Tl}$ & T2 & T3 & T4 & T5 & Mean \\
\hline Co 8021 & 0.662 & 0.575 & 0.594 & 0.611 & 0.542 & 0.597 & 37.27 & 36.01 & 36.98 & 38.18 & 31.33 & 35.95 & 72.73 & 56.23 & 70.1 & 72.25 & 48.44 & 73.51 \\
\hline Co 85019 & 0.684 & 0.647 & 0.662 & 0.674 & 0.633 & 0.660 & 40.11 & 37.7 & 38.61 & 39.29 & 35.5 & 38.24 & 81.34 & 68.37 & 75.48 & 77 & 65.35 & 56.31 \\
\hline Co 2001-13 & 0.659 & 0.609 & 0.642 & 0.642 & 0.576 & 0.626 & 39.18 & 37.41 & 38.11 & 40.14 & 33.09 & 37.59 & 70.47 & 53.18 & 61.04 & 72.48 & 46.48 & 69.48 \\
\hline Co 97010 & 0.664 & 0.608 & 0.608 & 0.629 & 0.516 & 0.605 & 39.15 & 34.57 & 35.12 & 35.63 & 29.09 & 34.71 & 69.73 & 48.28 & 55.66 & 67.41 & 40.45 & 72.51 \\
\hline Co 99004 & 0.680 & 0.644 & 0.658 & 0.664 & 0.615 & 0.652 & 39.61 & 37.48 & 39.56 & 40.66 & 33.73 & 38.21 & 79.62 & 63.57 & 68.21 & 79.55 & 56.44 & 59.17 \\
\hline Co 94012 & 0.667 & 0.632 & 0.653 & 0.652 & 0.597 & 0.640 & 38.72 & 37.17 & 38.9 & 39.56 & 35.85 & 38.04 & 80.32 & 70.27 & 75.27 & 76.51 & 60.18 & 57.82 \\
\hline Co 95007 & 0.662 & 0.606 & 0.614 & 0.607 & 0.557 & 0.609 & 38.99 & 36.15 & 37.81 & 35.04 & 32.44 & 36.09 & 70.45 & 50.33 & 56.3 & 73.62 & 45.17 & 73.51 \\
\hline Co 97009 & 0.668 & 0.644 & 0.653 & 0.654 & 0.600 & 0.644 & 40.18 & 37.67 & 39.52 & 38.6 & 33.95 & 37.98 & 70.51 & 51.5 & 56.48 & 68.38 & 42.21 & 56.31 \\
\hline Mean & 0.668 & $\begin{array}{c}0.621 \\
\text { SEd }\end{array}$ & 0.636 & 0.642 & $\begin{array}{c}0.580 \\
C D\end{array}$ & & 39.15 & $\begin{array}{c}36.77 \\
\text { SEd }\end{array}$ & 38.08 & 38.39 & $\begin{array}{c}33.12 \\
C D\end{array}$ & & 75.33 & $\begin{array}{c}58.72 \\
\text { SEd }\end{array}$ & 64.57 & 73.75 & $\begin{array}{c}51.63 \\
C D\end{array}$ & \\
\hline $\mathrm{T}$ & & 0.243 & & & 0.483 & & & 0.355 & & & 0.706 & & & 0.0021 & & & 0.0041 & \\
\hline V & & 0.192 & & & 0.382 & & & 0.281 & & & 0.559 & & & 0.0016 & & & 0.0031 & \\
\hline$T \times V$ & & 0.544 & & & 1.082 & & & 0.794 & & & 1.580 & & & 0.00478 & & & 0.0095 & \\
\hline
\end{tabular}


genotype $x$ treatment interaction was significant (Table 3). SPAD chlorophyll index and relative water content also showed similar trend and significant interactions suggest the physiological mechanisms adversely affected by salinity. Nevertheless, genotypes Co 85019, Co 94012 and Co99004 recorded higher fluorescence, SPAD index and RWC suggesting tolerance mechanism operating. Reduction in chlorophyll fluorescence and SPAD index are indications of impaired physiological function resulting in reduced physiological efficiency.

\section{Harvest Traits}

\section{Plant height}

There was a marked reduction in stalk length in all salt treatments $\left(\mathrm{T}_{2}\right.$ to $\left.\mathrm{T}_{5}\right)$ when compared to control (Table 2$)$. In control $\left(\mathrm{T}_{1}\right)$ it varied from $197 \mathrm{cms}$ (Co 8021 ) to $238 \mathrm{cms}$ (Co 85019). In treatments $\mathrm{T}_{2}$ and $\mathrm{T}_{5}$ the reduction in shoot length was elevated but in $\mathrm{T}_{3}$ and $\mathrm{T}_{4}$ the reduction was comparatively less. In $\mathrm{T}_{2}$ it ranged from 124.59 (Co 97010) to 190.20 (Co 85019) and in $\mathrm{T}_{5}$ higher reduction was noticed. In $\mathrm{T}_{5}$ lowest value measure was found in the genotype Co $97010(96.18 \mathrm{~cm})$ and the highest length was recorded in the genotype Co $85019(229.13 \mathrm{~cm})$. Shoot growth rate reduced even under mild salinity (EC of $2 \mathrm{dSm}-1)$ in sugarcane cultivars [16].

\section{Number of Stalks}

Number of stalks has decreased in all treatments $\left(\mathrm{T}_{2}\right.$ to $\left.\mathrm{T}_{5}\right)$ when compared to control (Table 2). In control $\left(\mathrm{T}_{1}\right)$ it varied from 4.33 in Co 97010 to 7.67 in Co 85019. In $\mathrm{T}_{2}$ it ranged from 2.67 in genotype Co 97010 to 6.33 in Co 85019 . $_{2}$ and $\mathrm{T}_{5}$ severely affected the stalk number. In $\mathrm{T}_{5}$, Co 85019 recorded the highest number (6.33) when compared to all other genotypes. The results pertaining to number of stalks and cane yield showed significant variation among the tested sugarcane varieties in saline condition [17].

\section{Single Cane Weight}

Single cane weight reduced due to salt treatment at all growth stages studied (Table 2 ). In $\mathrm{T}_{5}$ ranged from $428.3 \mathrm{~g}$ (Co 95007) to $1177.4 \mathrm{~g}$ (Co 85019) in $\mathrm{T}_{4}$. In control $\left(\mathrm{T}_{1}\right)$ the range was between $896.7 \mathrm{~g}$ (Co 97010) to 1,343g (Co $85019)$. There was very sharp decline in single cane weight in both $\mathrm{T}_{2}$ and $\mathrm{T}_{5}$. In $\mathrm{T}_{2}$ it ranged from 526.1g in Co 97010 to $777.9 \mathrm{~g}$ in $\mathrm{Co}_{9} 9004$ and in $\mathrm{T}_{5}$ it was from $428.3 \mathrm{~g}$ in $\mathrm{Co}$ 97009 to $937.1 \mathrm{~g}$ in Co 85019 . Treatments, $\mathrm{T}_{3}$ and $\mathrm{T}_{4} \mathrm{did}$ not affect the single cane weight in with comparison with $\mathrm{T}_{5}$. The results suggested that the effect of salt treatments during $\mathrm{T}_{2}$ and $\mathrm{T}_{5}$ were severe effect and also found to be critical. Reduction in single cane weight due to salt stress and considerable variation for salt tolerance in the sugarcane germplasm has been reported [18].

\section{Cane Yield}

The yield data (Table 2) indicated a remarkable variation among the genotypes. In control (T1) Co 85019 has recorded $10.31 \mathrm{~kg}$

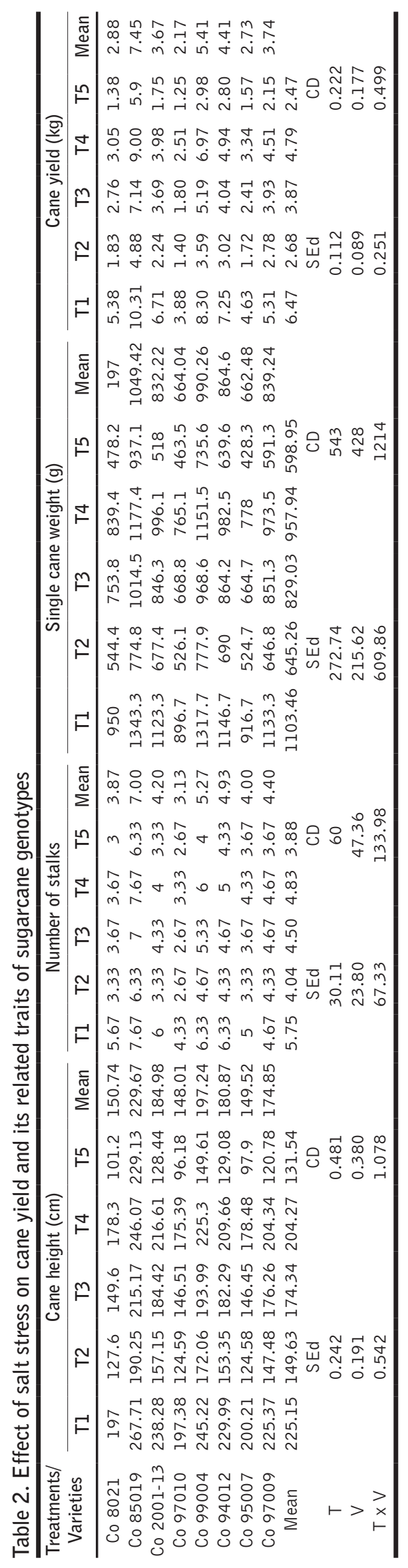


which was the highest cane yield/pot among all the genotype and lowest was found to be $3.88 \mathrm{~kg}$ in Co 97010 . The treatments $\mathrm{T}_{2}$ and $\mathrm{T}_{5}$ has similar trend, the highest reduction was found in the genotype Co 97010 ( $1.40 \mathrm{~kg}$ in $\mathrm{T}_{2}$ and $1.25 \mathrm{~kg}$ in $\mathrm{T}_{5}$ ), similarly the genotypes Co 8021 and Co 95007 recorded low weight below $2 \mathrm{~kg}$. In the treatments $\mathrm{T}_{3}$ and $\mathrm{T}_{4}$ the genotypes were not affected as compared to $\mathrm{T}_{2}$ and $\mathrm{T}_{5}$. From this result, it is inferred that the formative phase is critical apart from stress imposed at all other growth stages. Earlier finding also showed reduction in cane yield in sugarcane genotypes due to salinity [19].

At harvest the number of stalks/pot showed significant variation among genotypes as well treatments. Similarly, yield contributing traits viz, single cane weight and cane height also showed significant reduction due to salinity treatment imposed at different growth stages (Table 2). Highest reduction was recorded in treatment $\mathrm{T}_{5}$ followed by $\mathrm{T}_{2}$. The genotype $\mathrm{x}$ treatment interaction was significant (Table 3 ).

\section{Juice Quality}

Brix $\%$, purity $\%$, sucrose $\%$ and CCS\%

Salt treatment had negative impact on brix \% percentage, except for a few varieties which showed improvement in brix value. In $\mathrm{T}_{5}$ very low birx was observed in genotype Co 8021 (17.03\%) followed by Co 95007 (17.17\%). In $\mathrm{T}_{2}$ (salt treatment given during formative phase) it varied from $17.73 \%$ in Co 8021 to $24.03 \%$ in Co 94012. In $\mathrm{T}_{3}$ highest brix\% was recorded in Co 99004 (22.4\%) and Co 2001-13 (21.03) and the lowest was observed in Co 8021 (18.47\%). In $\mathrm{T}_{4}$ brix\% ranges from $19 \%$ in Co 8021 to $22.7 \%$ in Co 99004. In $\mathrm{T}_{5}$, Co 99004 has highest brix of $21.03 \%$ and Co 8021 has the lowest brix value of $17.17 \%$. The same trend was also observed with juice purity, sucrose and CCS\%. Effects of salinity, on brix, pol and conductivity were very similar, indicating that the response of juice quality to salinity is predictable $[20,21]$

\section{Sodium, Potassium and Chloride}

The amount of sodium, potassium and chloride in juice rose in salt treatment. The genotype Co 97010 showed highest salt content among the genotypes studied while, the genotype Co 99004 had least salt content. The genotype Co 85019 also has shown elevated levels of salts, which indicates storage of salts in juice.

Brix \%, purity $\%$, sucrose $\%$ and CCS\% reduced in all the treatments as compared to control in all the genotypes (figla-d). The treatment $\mathrm{x}$ genotype interaction was significant (Table 4).

In juice, $\mathrm{Na}$ content increased in all the treatments and in all varieties indicating the higher uptake of $\mathrm{Na}$. Na content in the juice was highest in $\mathrm{T}_{5}$ and in genotypes Co 85019, Co 8021, Co 97010 and Co 95007. Sodium is a non-essential element which affects the quality of the produce in agricultural crops. Potassium and chloride also increased and the trend was similar to $\mathrm{Na}$ (fig 2a, b, and c). The results are in line with earlier reports on sugarcane [21]. The treatment $x$ genotypes interactions were significant (Table 4). Plant tolerance to salinity was reported to be closely related to the $\mathrm{Na}^{+}$: $\mathrm{K}^{+}$ratio in the cell than the absolute $\mathrm{Na}^{+}$concentration $[22,23]$.

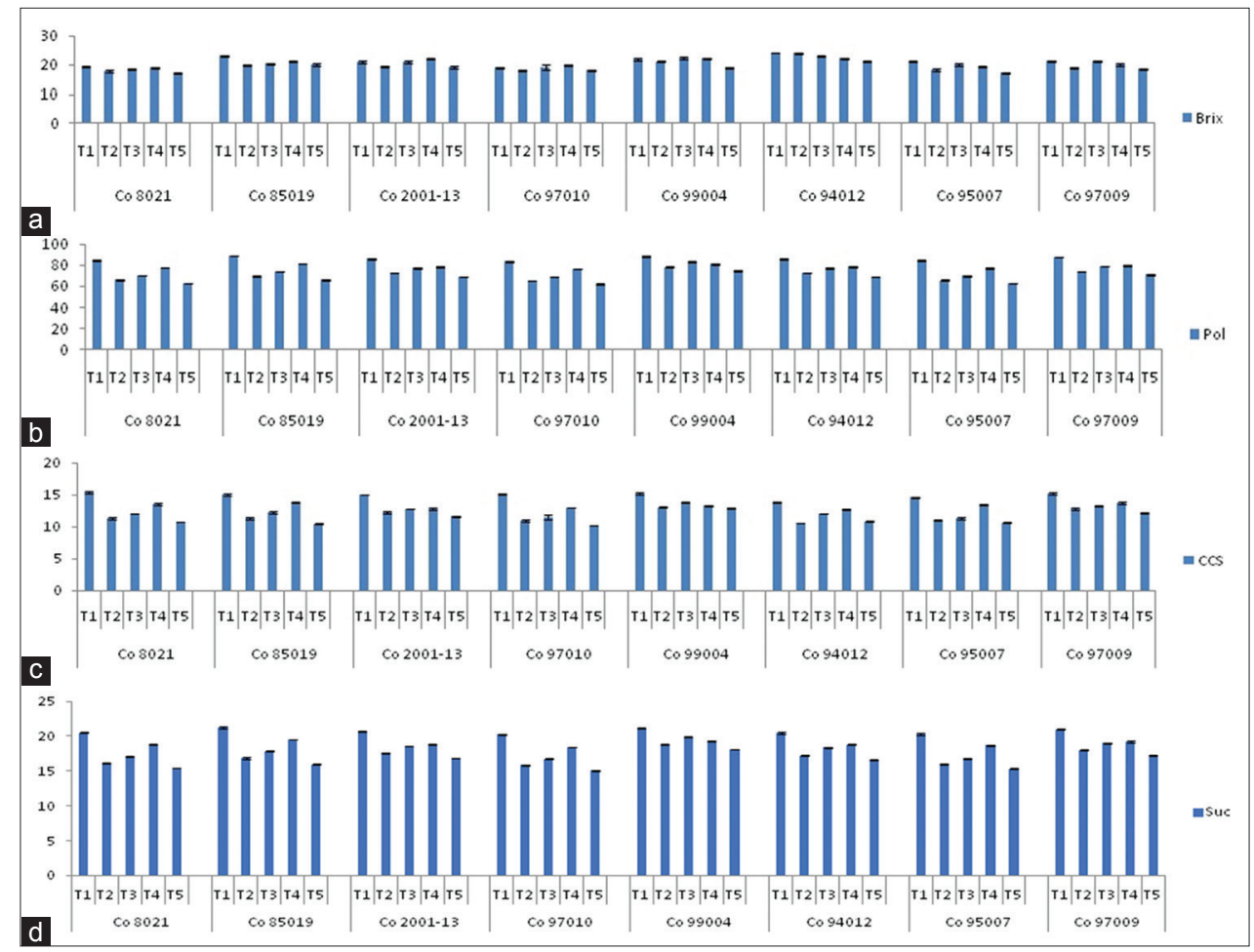

Figure 1: Effect of salinity on (a) Brix, (b) Purity, (c) CCS\%, (d) Sucrose\%. Error bars are indicated on the graph. Standard errors $(n=3)$ 


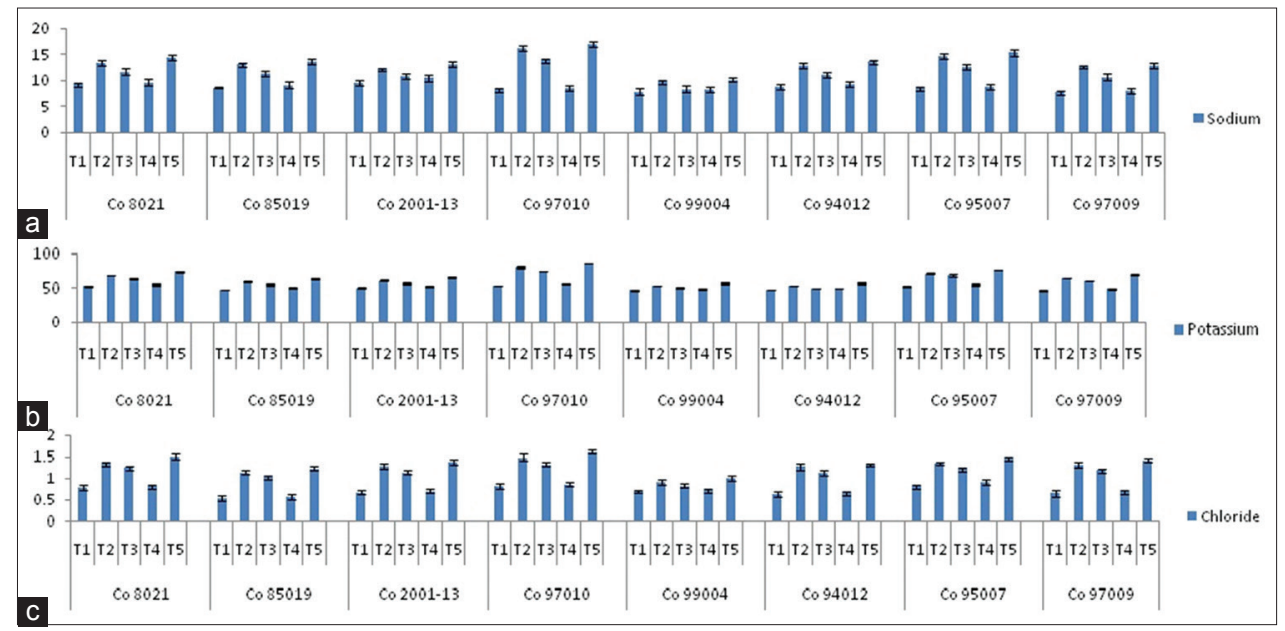

Figure 2: Effect of salinity on (a) Sodium, (b) Potassium \& (c) Chloride .Error bars are indicated on the graph. Standard errors $(n=3)$

Table 3: Two way ANOVA on NMC, SCW, Weight, Plant Height, Chlorophyll fluorescence, SPAD Chlorophyll \& RWC

\begin{tabular}{|c|c|c|c|c|c|c|c|c|}
\hline Factor & $\mathrm{df}$ & $\frac{\text { F Ratio probability }}{N M C}$ & Single cane weight & Weight/pot & Plant Height & Chlorophyll Fluorescence & SPAD Chlorophyll & RWC \\
\hline Variety & 7 & $46.40 * * *$ & $45.46 * * *$ & $78.58 * * *$ & $12128.47 * * *$ & $241.05^{* * *}$ & $28.25 * * *$ & $1560.49 * * *$ \\
\hline Salinity & 4 & $30.21^{* * *}$ & $157.58 * * *$ & $115.77 * * *$ & $36072.20 * * *$ & $744.05^{* * *}$ & $143.70 * * *$ & $5616 * * *$ \\
\hline Var X Sal & 28 & $1.620 * * *$ & $0.814 * * *$ & $1.674 * * *$ & $330.71 * * *$ & $17.09 * * *$ & $3.5^{* * *}$ & $64.06 * * *$ \\
\hline Error & 80 & $35.33 * * *$ & $544064 * * *$ & $44632220 * * *$ & $78.29 * * *$ & $0.0027 * * *$ & $75.8^{* * *}$ & $36 * * *$ \\
\hline Total & 119 & $244.80 * * *$ & $7150552 * * *$ & $636067442^{* * *}$ & $233447.30^{* * *}$ & $0.179 * * *$ & $900.61^{* * *}$ & $15683.18^{* * *}$ \\
\hline
\end{tabular}

Level of significance: $* * *$ indicate significant difference at $P \leq 0.001$

Table 4: Two way ANOVA on Brix, Purity, CCS\%, Sucrose\%, Sodium, Potassium \& Chloride

\begin{tabular}{|c|c|c|c|c|c|c|c|c|}
\hline Factor & $d f$ & $\frac{\text { F Ratio probability }}{\text { Brix }}$ & Purity & CCS & Sucrose & Sodium & Potassium & Chloride \\
\hline Variety & 7 & $343.77 * * *$ & $1569.38 * * *$ & $279.51 * * *$ & $1224.28 * * *$ & $82.65 * * *$ & $1365 * * *$ & $85.15^{* * *}$ \\
\hline Salinity & 4 & $261.47 * * *$ & $11570 * * *$ & $2695 * * *$ & $10015.43 * * *$ & $548.15^{* * *}$ & $3221 * * *$ & $754.15^{* * *}$ \\
\hline Var X Sal & 28 & $17.27 * * *$ & $106.17 * * *$ & $42.30 * * *$ & $98.87 * * *$ & $14.6 * * *$ & $94 * * *$ & $6.19 * * *$ \\
\hline Error & 80 & $7.62 * * *$ & $9.06 * * *$ & $1.54 * * *$ & $0.558 * * *$ & $19.06 * * *$ & $38 * * *$ & $0.239 * * *$ \\
\hline Total & 119 & $382.52 * * *$ & $6832 * * *$ & $270.54 * * *$ & $359.71 * * *$ & $773 * * *$ & $11977^{* * *}$ & $11.551 * * *$ \\
\hline
\end{tabular}

Level of significance: $* * *$ indicate significant difference at $P \leq 0.001$

\section{CONCLUSION}

In this study, a few sugarcane genotypes response towards phasic salt treatment was observed. From the treatments it was found that T2 (salt treatment during formative phase) and T5 (salt treatment throughout all the growth phases) were the critical phases. The genotypes Co 85019 followed by Co 99004 were found to be the best surviving when comparing all the other genotypes. These genotypes could be used in saline lands for occurring good yield.

\section{ACKNOWLEDGEMENTS}

The authors are thankful to the Director, ICAR-Sugarcane Breeding Institute, Coimbatore for providing necessary facility and support to carry out the research facility and support to carry out the research work successfully.

\section{REFERENCES}

1. Wei W, Bilsborrow EP, Hooley P, Fincham AD, Lombi E, Forster PB. Salinity induced differences in growth, ion distribution and partitioning in Barley between the cultivar Maythorpe and its derived mutant Golden Promise. Plant and soil. 2003; 183:191-250.

2. Smita Kumari, Jha CK. Influence of sodium chloride induced salinity on growth, yield and juice quality of promising Sugarcane genotypes. International Journal of Current Microbiology and Applied Sciences. 2018; 7(6):1366-1375

3. Rozeff N. Sugarcane and salinity. Sugarcane. 1995; 5:8-19.

4. Blackburn. Sugarcane tropical agriculture series longman. London and New York. 1984; 68-74.

5. Ahmad Heidari, Ali Bandehagh, Mahmood Toorchi. Effects of $\mathrm{NaCl}$ stress on chlorophyll content and chlorophyll fluorescence in Sunflower (Helianthus annuus L.) Lines. YYU Journal of Agricultural Science. 2014; 24(2): 111-120.

6. Zvi Plaut, Frederick C, Meinzer, Evelyn Federman. Leaf development, transpiration and ion uptake and distribution in Sugarcane cultivars grown under salinity. Plant and Soil. 2000; 218 (1/2):59-69.

7. Kenta Watanabe, Mai Nakabaru, Eizo Taira, Masami Ueno, Yoshinobu Kawamitsu. Relationships between nutrients and sucrose concentrations in Sugarcane juice and use of juice analysis 
for nutrient diagnosis in Japan. Plant production Science. 2015; 19(2):215-222

8. Altaf Hussain, Zafar lqbal Khan, Muhammad Hamid Rashid, Muhammad Ashraf, Muhammad Saeed Akhtar. Soil Salinity Effects on Sugarcane productivity, biochemical characteristics and invertase activity. Pakistan Journal of Life and Social Sciences. 2003; 1(2): 114-121.

9. Barrs HD, Weatherley PE. A re-examination of the relative turgidity techniques for estimating water deficits in leaves. Australian Journal of Biological Sciences. 1962; 15,413-428.

10. Meade GP, Chen JC. Cane sugar handbook. 1977.

11. Piper CS. The symptoms and diagnosis of minor-element deficiencies in agricultural and horticultural crops. Empire Journal of Experimental Agriculture. 1940; 8:85-100.

12. Li M, Yang D, LiW. Leaf gas exchange characteristics and chlorophyll fluorescence of three wetland plants in response to long-term soil flooding. Photosynthetica. 2007; 45(2):222-228.

13. Baker N, Rosenqvist E. Applications of chlorophyll fluorescence can improve crop production strategies: An examination of future possibilities. Journal of Experimental Botany. 2004; 55:1607-1621.

14. Anitha RP, Christy Nirmala Mary, Antony Joseph Ravi Savery M, Sritharan N, Purushothaman RS. Differential responses of Sugarcane (Saccharum officinarum L.) genotypes under salt stress condition. Plant Archives. 2015; 15(2): 1055-1060.

15. Vasantha S, Venkataramana S, Gururaja Rao PN, Gomathi R. Long term salinity effect on growth, photosynthesis and osmotic characteristics in Sugarcane. Sugar Tech. 2010; 12 (1):5-8.
16. Meinzer FC, Plaut Z, Saliendra NZ. Carbon isotope discrimination, gas exchange and growth of Sugarcane cultivars under salinity. Plant Physiology 1994; 104: 521-6.

17. Alam KS, Islam MS, Hossain GMA, Alam KM. Screening salinity tolerant Sugarcane varieties considering yield, quality and economic parameters in Southern region of Bangladesh. Eco-friendly Agriculture Journal. 2018; 11(03):38-42.

18. Suriyan Cha-um, Satjaporn Chantawong, Chareerat Mongkolsiriwatana Muhammad Ashraf, Chalermpol Kirdmanee. Field screening of Sugarcane (Saccharum spp.) mutant and commercial genotypes for salt tolerance. Notulae Botanicae Horti Agrobotanici. 2013; 41(1):286-293.

19. Shamshad Akhtar, Abdul Wahid, Muhammad Akram, Ejaz Rasul. Effect of $\mathrm{NaCl}$ salinity on yield parameters of some Sugarcane genotypes. International Journal of Agricultural Biology. 2001; 3(4):507-509.

20. Lingle SE, Weigand CL. Soil salinity and Sugarcane juice quality. Field Crop Research 1997: 54: 259-68.

21. Vasantha SR, Gomathi, P Rakkiyappan. Sodium content juice and jaggery quality of Sugarcane genotypes under salinity. Electronic Journal of Biological Sciences. 2009; 1(1):33-38.

22. Benzyl ML, Reuveni M. Cellular mechanisms of salt tolerance in plant cells. Horticulturral Reviews.1994; 16:33-69.

23. Qian YL, Wilhelm SJ, Marcum KB. Comparative response of two entucky bluegrass cultivars to salinity stress. Crop Science. 2001; 41:1895-1900. 